\title{
ALGORITHM FOR ASSESING SOIL REHABILITATION OF STERILE DUMPS
}

\author{
ANDREEA BRASOVAN ${ }^{a}$, RAMONA FLAVIA BURTESCU ${ }^{b}$, \\ NELI-KINGA OLAH ${ }^{b, c^{*}}$, IOAN PETEAN $^{\mathrm{d}}$, VLAD CODREA ${ }^{\mathrm{a}}$, \\ ANDREI BURTESCU
}

\begin{abstract}
Ileana Veche is the most representative waste rock (sterile) dump formed by the coal mining activities in Lupeni (Petroşani Basin). We developed an algorithm based on the computational engineering concepts in order to establish the connection between the waste rock soil particles composition and the dump rehabilitation by Scots Pine (Pinus sylvestris). The results show that the lleana Veche pit coal dump features minerals suitable for plants growth like: calcite, biotite, potassium feldspar and chemically inert one as quartz. The quantitative measurements prove that the soil minerals are enough to allow a fair growing of the $P$. sylvestris population able to start the soil type conversion from the entiantrosoil type to a more fertile one. The measurements found that the upper soil presents humus formation and features nitrogen and phosphorous while in the deeper layer are missing.
\end{abstract}

Keywords: coal mining, coal dump, rehabilitation, mineralogy, Petroşani Basin, Romania.

\footnotetext{
a Babeş-Bolyai University of Cluj-Napoca, 1 Kogălniceanu Str., 400084, Cluj-Napoca, Romania

b SC PlantExtrakt SRL, 407059 Rădaia. Cluj, Romania

c "Vasile Goldis" Western University of Arad, Faculty of Pharmacy, 86 Rebreanu Street, Arad, Romania

d Technical University of Cluj-Napoca, Faculty of Materials Science and Engineering, Muncii Ave. No.103-105, Cluj-Napoca, Romania

e Technical University of Cluj-Napoca, Faculty of Mechanical Engineering and Mechatronics, Muncii Ave. No.103-105, Cluj-Napoca, Romania

*Correspondent author: neliolah@yahoo.com
} 


\section{INTRODUCTION}

Petroşani is one of the main post-tectonic sedimentary basins of the Southern Carpathians. The sedimentary fillings are composed of Paleogene and Miocene deposits [1]. Several Paleogene coal beds were and still are exploited. The main coal deposits occur in the so-called "second (middle) horizon" or "lower productive", part of the Dâlja-Uricani Formation (early Eggerian) [2]. This formation bears 22 coal beds, but only 11 are thick enough to have economic value. The sedimentary succession includes repetitive interleaving of lacustrine (bituminous shale, coal), brackish (clay, marl, dysodyle shale) and subordinate marine deposits [1-3]. The bituminous coal was under the influence of the tectonic metamorphism, i.e. pressure and temperature due to the basin compression after its filling with sediments [4]. Such mining exploitation involved coal and sterile rocks (waste rock), which is stored in sterile dumps.

lleana Veche was the first dump resulted from Lupeni mining processes. It was built up by sterile discharging directly from the trolleys on a suspended railway system. It is oriented on east-western direction as a particularly consequence of sterile deposing. The dumping ceased in 1980. Nowadays it is fully covered by pines ( $P$. sylvestris) that seem to record a healthy growth. Planting trees is a proper solution to fix and greening the coal dumps as reported in literature $[5,6]$. $P$. sylvestris was also used abroad in cases of settling [7] and for plant-rehabilitation of the coal dumps [5, 6].

However, the dump was rebuilt in the last years in terraces and platforms, with low slope angles [8, 9, 34, 35]. To reduce the out-flow from the dump, two drainage systems were built, one on the northern side of the dump, which was connected to second drainage system on the western side.

According to the actual soil taxonomy, the soil covering this coal dump belongs to entiantrosoils $[10,28]$. Studies on these soils issued from industrial works, in terms of composition and morphology can yield important data for dump rehabilitation $[11,12]$. The landfills and dumps rehabilitation are very important works during environment ecology processing $[5,6]$. Some recent studies are following this trend also in Romania [13, 11, 12].

The environmental analysis and prediction tendency are to use modern computational algorithms [14, 15]. Even the environmental rehabilitation supported computational treatment and monitoring [16]. Recently, the computational and engineering algorithms are employed to modeling physical phenomena such as thermodynamic processes [17]. Such approach could be extended to other processes such as landfill and dumps rehabilitation. Further, we develop an algorithm to evaluate the rehabilitation process of lleana Veche sterile dump. 
The measure of the dump rehabilitation is related to the satisfactory response to the critical questions raised by the designed algorithm. The specific analyses performed on the soil samples leads to an answer to the algorithm questions. Further, the algorithm shows whether the rehabilitation process is well developed or not.

\section{RESULTS AND DISCUSSION}

The sterile resulting from the technological flow of coal exploitation is deposited in waste dumps. This constitutes the dumps entiantrosoil. In this case appear certain critical questions affecting the dump rehabilitation, ie the entiantrosoil transformation into a more fertile soil $[18,19,36]$. As mentioned before [17], some operational steps could be modeled by a general logic cycle instruction as presented in Eq. (1):

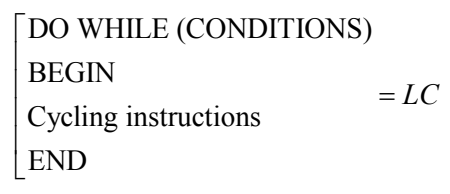

The algorithm could use such cycled instructions (LC) for each critical questions regarding the dump rehabilitation. Furthermore, the final algorithm will have a form like Eq. (2):

$$
\left[\begin{array}{l}
\text { REHABILITATION ALGORITHM } \\
\text { BEGIN } \\
L C_{1} \rightarrow L C_{2} \rightarrow L C_{\mathrm{n}} \\
\text { END }
\end{array}\right.
$$

We designed the algorithm suitable for any pit coal sterile dump rehabilitation considering the critical questions and presented cycling instruction. The logical scheme for the designed algorithm is presented in Fig.1. and it is suitable for any programming environment. It features all elements necessary for a proper computational program; each critical question " $Q$ " represents the cycling condition for each step meanwhile the remedy " $R$ " represents the cycling instruction. The "remedy" is cycled while the answer to the critical condition "Q" is proper. Once a step is passed, the following step is cycled until the FINISH instruction occurs.

Our research has been made for two soil samples, one from the surface $\left(A S_{1}\right)$ and another from a depth of $1 \mathrm{~m}\left(A S_{2}\right)$. 


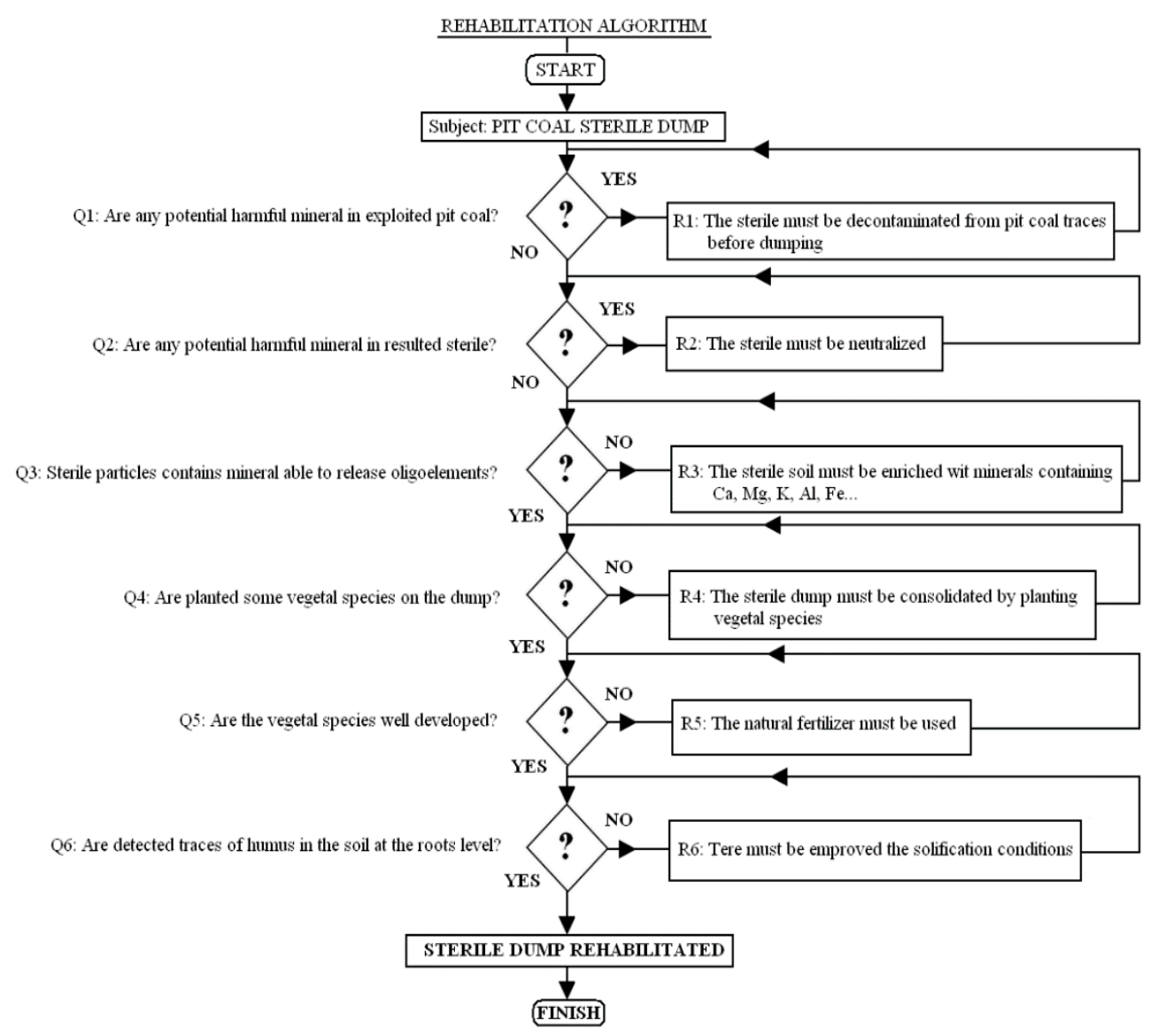

Figure 1. The sterile dump rehabilitation algorithm

$\mathrm{Q}_{1}$ question refers to the mineralogical composition of exploited coal and the possible/potentially harmful effect to the environment. The answer to this question has been elaborated in mineralogy and crystallography analyzes achieved by average coal sample. The diffraction results are shown in Figure 2.

The general appearance of the diffractogram (fig 2.a) shows an amorphous mass base conferring a specific allure with a "hump”. We observe that the overlapping variation identified distinct diffraction peaks which exceed the neutral background radiation. They are the result of the presence of accompanying minerals. Following the standard procedures has been identified these components. 

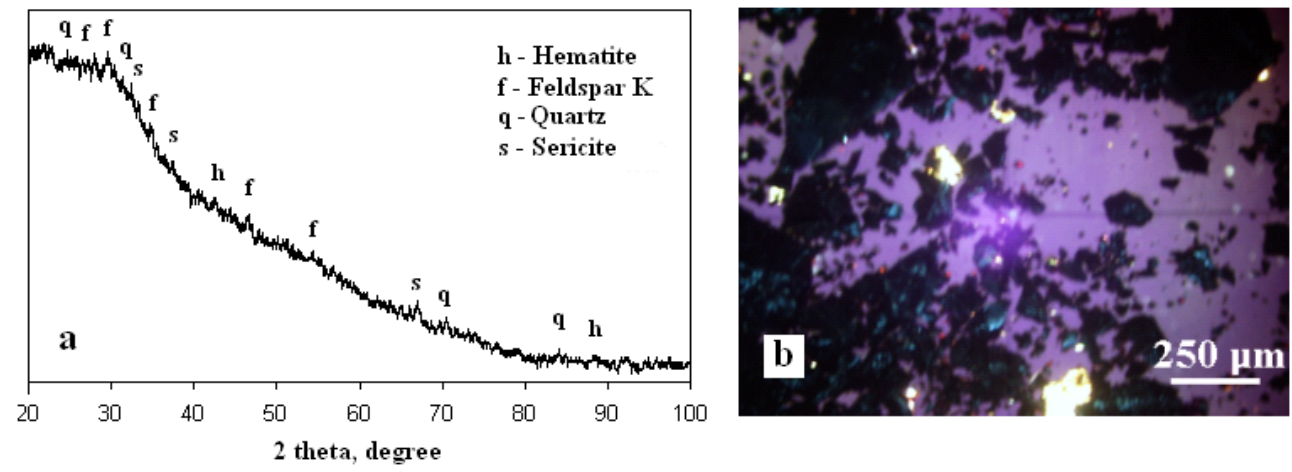

Figure 2. The pit coal from Lupeni average representative sample APCS:

a) X-ray diffraction pattern and b) optical cross polarized light microphotograph

In the coal from E.M. Lupeni have been identified the following minerals as crystalline constituents in coal sample: - $\mathrm{SiO}_{2}$ quartz, - $\mathrm{Fe}_{2} \mathrm{O}_{3}$ hematite, sericite, $\mathrm{KAl}_{2}\left(\mathrm{Si}_{3} \mathrm{Al}\right) \mathrm{O}_{10}(\mathrm{OH}, \mathrm{F})_{2},-\mathrm{K}\left(\mathrm{AlSi}_{3} \mathrm{O}_{8}\right)$ potassium feldspar.

Minerals found in the average coal sample correspond to the chemical composition reported in previous studies [20, 21, 22]. Low mineral content is proven by small peaks present in the diffractogram (fig. 2.a). Optical microscopy in polarized light confirmed the results obtained by X-ray diffraction, (fig. 2.b). Are observed quartz particles with gray-green color, with a diameter of $25 \mu \mathrm{m}$, potassium feldspar particles which appear bright white with a diameter of $200 \mu \mathrm{m}$, hematite particles which color vary from dark blue to gray and then to brown-red, depending on the particle position toward the optical microscope axis.

The diffractogram allure is specific to an amorphous material, represented by the carbon mass specific to the coal. There were identified diffraction peaks specific to quartz, potassium feldspar, sericite and hematite, but with a very low relative intensity in relation to the diffractogram background. The minimum concentration of the crystalline compound identifiable with DRON 3 diffractometer is between $1-3 \%$ depending on the specificity and sample preparation. Diffraction peaks identified in diffractogram (fig 2.a) are very close to the detection limit, because it comes from a crystalline material content a little over $3 \%$. The fact itself indicates a very low content of crystalline material in the composition of investigated coal.

The information from literature indicates the ash content of the burning coal between $5-40 \%$ [4], that means between 5 and $40 \%$ sterile inclusions, which are usually present in crystalline form. Consequently by X-ray diffraction we 
can appreciate the content of crystalline material accompanying the investigated coal samples, to be around the $5 \%$, value for the summe of crystalline compounds. Therefore the investigated coal samples from Lupeni are of the highest quality. All minerals found in the average coal sample are commonly found in the natural environment and does not generates pollution risk.

The results of elementary analyzes performed for sample are consistent with the results obtained by Rebrişoreanu 2002 [22]. The major component is the silicon from quartz. Silicon, aluminum and potassium oxides are found in potassium feldspar and sericite. $\mathrm{Fe}_{2} \mathrm{O}_{3}$ iron oxide crystallized in the rhombohedral system is present in hematite.

Crystalline inclusions from coal sample can be found in sterile dump only in certain circumstances, but their dominant effect is found in ash from burnt coal. Recent studies show that potassium feldspar and sericite is converted to mullite, while hematite is dried and becomes goetia [23]. The sterile dump is not normally exposed to intense combustion, therefore it is expected that some crystalline phases to maintain a long period of time. In addition, it is possible that some crystalline inclusions from the carbon not to be found in sterile dump due to different petrogenesis.

The answer to the critical question $Q_{1}$ is negative, which can be observed from the results of average coal sample measurements. This means that we could pass to the evaluation of critical question $Q_{2}$. This item refers to the mineralogical composition of the soil samples $A S_{1}$, $\mathrm{AS}_{2}$, for the sterile dump lleana Veche from Lupeni.

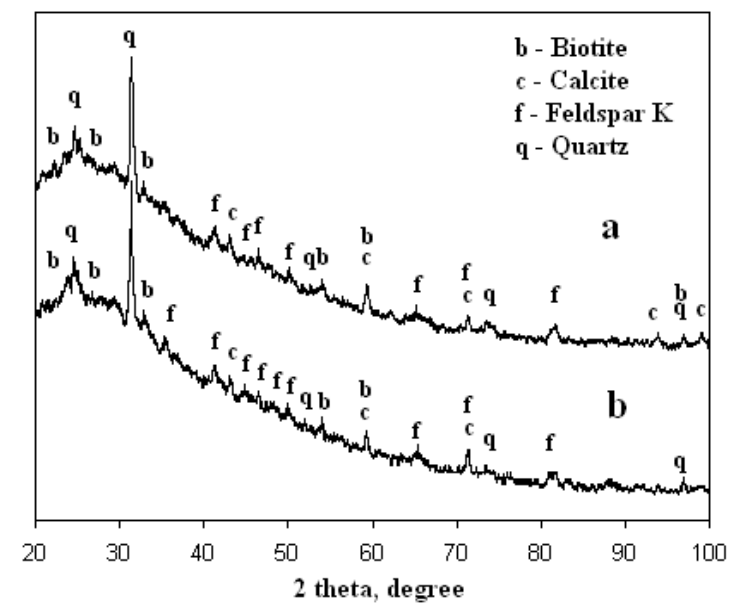

Figure 3. X-ray diffraction patterns for the soil samples collected from lleana Veche - Lupeni sterile dump: a) $A S_{1}$ and b) $A S_{2}$ 
The two soil samples $A S_{1}$ and $A S_{2}$ collected from the sterile dump were investigated by X-ray diffraction and the obtained patterns are shown in Figure 3. In both samples are observed diffraction peaks well defined and different stages of crystallization.

$\mathrm{AS}_{1}$ collected from the roots level of $P$. sylvestris is rich in quartz and potassium feldspar (minerals encountered in average coal sample). We also found significant amounts of $\mathrm{CaCO}_{3}{ }^{-}$- calcite and $\mathrm{H}_{4} \mathrm{~K}_{2} \mathrm{Mg}_{6} \mathrm{Al}_{2} \mathrm{Si}_{6} \mathrm{O}_{24}-$ biotite. The minerals found in $\mathrm{AS}_{1}$ are very similar to those found in soil samples from the sea buckhtorn level roots of the West Well 7 from Vulcan sterile dump [24]. These minerals come from sterile intercalations of coal layers of sedimentary formation Dâlja-Uricani represented by sandstones and marl.

Therefore, quartz is the major component of sterile dump, about $50 \%$, as evidenced by the diffractogram (fig. 3 ), in which the diffraction peaks are $100 \%$. Diffraction peaks for other minerals not exceed $50 \%$ and are represented in $\mathrm{AS}_{1}$ by potassium feldspar, calcite and biotite. Elemental analysis provides a more precise distribution of the elements from $A S_{1}$. Lack of hematites and sericites from $A S_{1}$ and $A S_{2}$ shows that coal is well sorted / separate from sterile.

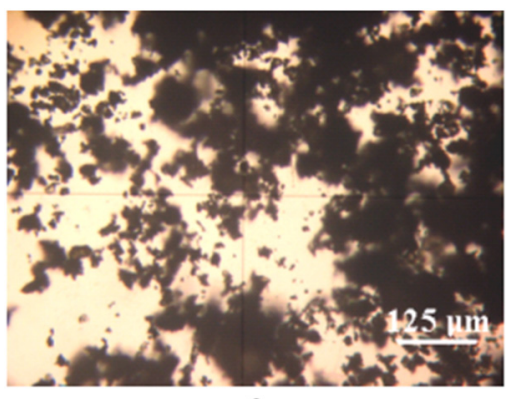

a

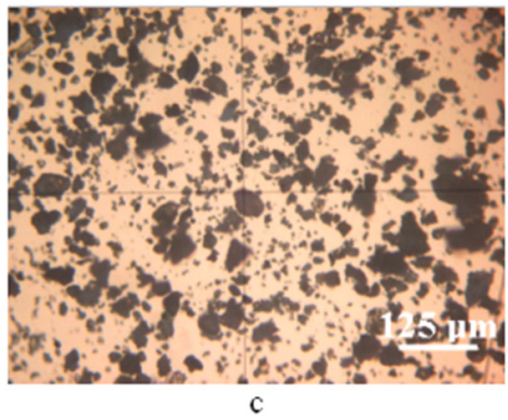

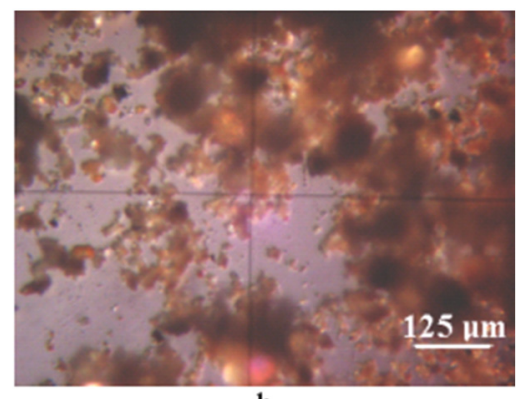

b

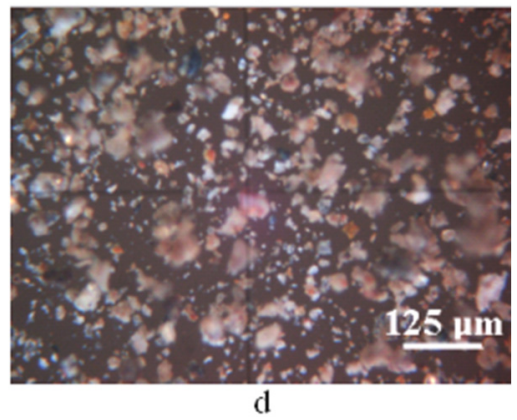

Figure 4. Optical microscopy inspection of $A S_{1}$ and $A S_{2}$ samples:

a) $A S_{1}$ transmitted light; b) $A S_{1}$ cross polarized light;

c) $A S_{2}$ transmitted light; d) $A S_{2}$ cross polarized light. 
X-ray diffraction pattern for $\mathrm{AS}_{2}$ (fig. 3) reveals similar mineralogical aspects as $A S_{1}$, because also in this sample we find quartz, potassium feldspar, biotite and calcite particles. This proves that both samples were collected from the same sterile dump and come from sediments present between coal layers from Lupeni. This gives a negative answer the critical question $\mathrm{Q}_{2}$.

Critical question $Q_{3}$ refers to the ability of soil to release oligoelements as $\mathrm{Ca}, \mathrm{Mg}, \mathrm{K}, \mathrm{Fe}, \mathrm{Al}$, useful for vegetation developement. The answer depends on the resulting data from X-ray diffraction reported to the microstructure sample.

$\mathrm{AS}_{1}$ sample provides information about the particle size between 20 and $150 \mu \mathrm{m}$ as shown in Figure 4.a. The distribution of particles is unusual as an aspect for industrially processed particles [23]. Further data was obtained by optical microscopy in crossed polarized light (fig. 4.b). In this figure it can be observed the quartz minerals such as grain, yellowish-brown calcite, potassium feldspar and biotite (the reddish-brown due to the presence of $\mathrm{Fe}$ and $\mathrm{Mg}$ ), in diameter around $20 \mu \mathrm{m}$ related to the organic material. The organic material is expected to be humus formed by $P$. sylvestris roots that populate the sterile dump.

$\mathrm{AS}_{2}$ microstructure (fig. 4.c) reveals a totally different particle distribution than $A S_{1}$. The particles are well dispersed, individually disposed, without any binder. The crossed polarized light (fig. 4.d) reveals a large amount of quartz and calcite minerals, similar to spherical grains with average diameter around $20 \mu \mathrm{m}$, while the potassium feldspar and biotite has a lamellar - tabulated form with an average plan diameter of $15 \mu \mathrm{m}$. In terms of the microstructural investigations $A S_{2}$ is an initial entiantro-soil while $A S_{1}$ is a rehabilitated soil.

The quartz particles are stable physically and chemically, representing the foundation soil. Calcite particles are very sensitive to interaction with water, being able to release $\mathrm{Ca}^{2+}$. Recent studies have revealed that the clay minerals are capable of releasing ions under conditions of high humidity [25, 26]. Considering this hypothesis, the $\mathrm{AS}_{1}$ and $\mathrm{AS}_{2}$ soils are able to provide the most important oligoelements required to develop vegetation. The potassium feldspar is able to release $\mathrm{K}^{+}$and $\mathrm{Al}^{3+}$, while the biotite is able to release $\mathrm{Mg}^{2+}$ and $\mathrm{Fe}^{3+}$. This is supported by X-ray fluorescence analysis for $\mathrm{AS}_{1}$ and $\mathrm{AS}_{2}$, the data are presented in Table 1.

Table 1. The XRF elemental analysis results for the soil samles

\begin{tabular}{|l|l|l|l|l|l|l|}
\hline Compound & $\mathbf{S i}^{4+}$ & $\mathbf{A l}^{3+}$ & $\mathbf{F e}^{3+}$ & $\mathbf{C a}^{2+}$ & $\mathbf{K}^{+}$ & $\mathbf{M g}^{2+}$ \\
\hline $\mathrm{AS}_{1}, \mathrm{wt} \%$ & 45.5 & 8.83 & 4.37 & 4.09 & 1.65 & 1.03 \\
\hline $\mathrm{AS}_{2}, \mathrm{wt} \%$ & 49.5 & 8.65 & 4.69 & 3.90 & 1.43 & 0.82 \\
\hline
\end{tabular}


The data from the Table 1 show that the sample $A S_{1}$ is able to supply enough $\mathrm{Ca}, \mathrm{Mg}, \mathrm{K}, \mathrm{Fe}$ to sustain a vegetation developement. The answers to the $Q_{3}$ critical question is definitely affirmative, and the evaluating of the rehabilitation process could move forward to the following critical questions. The visual investigations performed on the sterile dump during the samples collection, answer affirmative to the critical questions $Q_{4}$ and $Q_{5}$, which prove that the minerals from the sterile particles are to ensure the good development of the population of $P$. sylvestris. The covering the sterile dump with pine plantations proves to be a good method of rehabilitation. The results are in accordance with previously published data [7].

A critical question to the designed algorithm remains the $Q_{6}$ question. Answering this question is beside the soil analysis, much improved and presented in Table 2 with the standards values [27].

Table 2. Results of soil formation parameters

\begin{tabular}{|l|c|c|c|c|}
\hline \multirow{2}{*}{$\begin{array}{c}\text { Soil formation } \\
\text { parameter }\end{array}$} & \multicolumn{4}{|c|}{ Sterile dump lleana Veche } \\
\cline { 2 - 5 } & $\mathbf{A S}_{\mathbf{1}}$ & $\mathbf{A S}_{\mathbf{2}}$ & Standard values & Evaluation \\
\hline $\mathrm{pH}$ & 7.20 & 7.08 & $0-14$ & Neutral \\
\hline Humus, \% & 9 & 0.32 & $2.57-15$ & Good content at roots level \\
\hline Total nitrogen, \% & 0.46 & 0.05 & $0.02-0.77$ & Moderate content \\
\hline Phosphorus, ppm & 0.11 & 0.06 & Max. 11 & Low content \\
\hline Potassium, ppm & 60.00 & 20.00 & Max. 96 & Moderate content \\
\hline
\end{tabular}

The $\mathrm{pH}$ of the $A S_{1}$ sample is very close to neutral value, which proves the balance between the acid behavior of the feldspar and biotite particles in contact with water, than the calcite particles, which proves an excellent basic behavior. Humus value is $9 \%$ for $A S_{1}$ while as for $A S_{2}$ is almost absent. The lack of humus in depth, in $\mathrm{AS}_{2}$ sample shows that the soil-forming agent is the life cycle of $P$. sylvestris population.

The transition from the $A S_{2}$ entiantrosoil to the fertile soil of the $\mathrm{AS}_{1}$ sample is also evidenced by the absorption of nitrogen and phosphorus from $\mathrm{AS}_{1}$ particles, which is closely related to pine roots action. The measured value for potassium is significant and corresponds to a common fertile soil with moderate potassium. This can be explained by the stable chemical bonds achieved of $\mathrm{K}^{+}$in the structure of potassium feldspar which influences the release of the $\mathrm{K}^{+}$ion in the aqueous solution. Finally, the answer to the critical question $Q_{6}$ is affirmative, and we can conclude that lleana Veche dump rehabilitation is well done. 


\section{CONCLUSIONS}

The designed algorithm proves to be suitable for assessing of the sterile dump rehabilitation through critical questions which refer to the influence of the soil mineralogical composition on the vegetation growth. This clearly shows that the successful rehabilitation of the sterile dump depends on the soil mineralogical composition. The designed algorithm could be developed into a proper programming environment with a better standard parameters database. It could be made in such a way to evaluate the state of sterile dump rehabilitation and to anticipate the needed measures to achieve a good level of rehabilitation. This algorithm can be applied as in the case of sterile dump West Well 7 from Vulcan which is rehabilitated with sea buckthorn or for the sterile dump from Câmpu lui Neag where we find more tree species and wild rose.

We employed a new modeling concept based on computational engineering in order to establish the relationship between the sterile soil particles composition and the dump rehabilitation by $P$. sylvestris. Our measurements established the mineralogical composition of lleana Veche pit coal dump soils, with quartz, calcite, biotite and potassium feldspar. The minerals found in soil are also found as inclusion minerals into the pit coal, along with few traces of hematite and sericite. However, we observe that the pit coal composition do not affect the mineral composition of the sterile dump soil, organic matter being less than $1 \%$ in initial state. The quartz particles are a very good support for a proper soil formation. Calcite, biotite, and potassium feldspar represent proper vegetation source with oligoelements such $\mathrm{Ca}, \mathrm{Mg}, \mathrm{K}, \mathrm{Fe}$ and $\mathrm{Al}$ in the presence of water.

The increasing value tendency of oligoelements in upper soil $A S_{1}$ was observed. Considering each modeling step evaluation, it results that the Ileana Veche pit coal dump has minerals suitable for vegetation growth (quartz, calcite, biotite and potash feldspar). The quantity of oligoelements provided by the soil minerals is enough to support the growing of the $P$. sylvestris population. According to this proposed computational model, the humus presence and the adsorption of phosphorous and nitrogen at the soil level confirms that the $P$. sylvestris population induce the transition from the entiantrosoil category to fertile one. Finally, we may conclude that the rehabilitation of Ileana Veche pit coal dump achieve a good level of rehabilitation. 


\section{EXPERIMENTAL SECTION}

\section{Soil sampling}

The soil samples were collected from the top surface and from a $1 \mathrm{~m}$ depth (beneath the $P$. silvestris roots), in ten representative collecting locations over the dump's surface. The average representative soil samples were obtained by mixing equal amounts from each sampling point. It result the top surface average sample $\left(A S_{1}\right)$ and depth average representative sample $\left(A S_{2}\right)$. The pit coal samples from Lupeni exploitation were collected from at least five different sorts. Each pit coal sample was grinded and equal quantities of resulted powder were mixed into an average pit coal sample (APCS).

\section{Mineralogical analysis}

Mineralogical analysis was performed on the average samples by X-ray diffraction (XRD) analyses, using DRON 3 diffractometer with data acquisition module and Matmec VI.0 software, the X-ray characteristic being for cobalt Co ka. The diffraction peaks were identified using Standard X-Ray Diffraction Data Base - MATCH 1.0 from Crystal impact Co. The results obtained by X-ray diffraction were certified by the optical microscopy analysis, using a Karl Zeiss Jena mineralogical optical microscope.

The elemental analysis was performed according to the standard sampling and operating procedures using a Rigaku ZSX100 X-ray fluorescence spectrometer (XRF) in order to measure the main elements corresponding to the minerals identified by XRD. There was used a WDXRF wavelength detector for a wide range of atomic species. The samples were dried at $80^{\circ} \mathrm{C}$ for $12 \mathrm{~h}$, powdered (325 mesh) and mixed with boric acid in a 1:4 ratio (100 mg of sample and $400 \mathrm{mg}$ of $\mathrm{H}_{3} \mathrm{BO}_{4}$ ). The mixture was pressed at $203 \mathrm{MPa}$ for 10 minutes, obtaining $2,5 \mathrm{~cm}$ diameter pellets of $100 \mathrm{mg} / \mathrm{cm}^{2}$ surface density. The results are read with the Spectra Plus software and the determination of elements is done using Dyna Match international database. The measurements and readings were made according to EN ISO 9001:2000. The final value represents the average of reading for 3 similar samples for both $A S_{1}$ and $A S_{2}$.

The $\mathrm{pH}$ determination was performed on a potentiometer device INULABß. The humus content in the $A S_{1}$ sample was measured by titration using Walkley-Black method [29, 30].

The nitrogen measurements were performed on a Panas-Wagner device according to the Kjeldahl method [31].

The phosphorus and potassium determinations were measured by Nikolov and Egner, Riehm, Domingo methods $[32,33]$ using a METERTECH SP 830 PLUS spectrometer. 


\section{REFERENCES}

1. E. Pop, "Monografia geologică a Bazinului Petroşani", Ed. Academiei Române, Bucureşti, 1993, 303.

2. V. Moisescu, Revue Roumaine de Géologie, Géophysique et Géographie, 1983, 27, 53.

3. V. Moisescu, "Contributions à la connaissance de la faune de mollusques eggeriens prélevée du forage 19-Hobiceni (Bassin de Petroşani). In: The Oligocene from the Transylvanian Basin Romania”, Cluj-Napoca, 1989, 275.

4. I. Petrescu, M. Ionescu, "Zăcăminte de huile din Oligocenul Superior-Miocenul Inferior. Zăcămintele din Bazinul Petroşani. In: Petrescu, I, Biţoianu, C, Nicorici, M, Mărgărit, Gh., Nicorici, E, Pătruţoiu, I, Todros, C, Popescu, D, lonescu, M, Duşa, A, Munteanu, A, Buda, A., Geologia zăcămintelor de cărbuni”, Ed. Tehnică, Bucureşti, 1987, 315, vol. 1, 387, vol. 2.

5. A.G. Khan, C. Kuek, T.M. Chaudhry, C.S. Khoo, W.J. Hayes, Chemosphere, 2000, 41, 197.

6. Z. Stêpniewska, A. Woliñska, W. Pióro, Polish Journal of Echology, 2007, 55 (2), 139.

7. G. Szarek-Łukaszewska, K. Grodzińska, Polish Journal of Echology, 2007, 55 (2), 261.

8. C. Biro, "Reabilitarea terenurilor degradate de activităţile antropice din Bazinul minier Petroşani” Ph.D. Thesis, Universitatea Petrosani, 2005.

9. I. Rotunjanu, "Asecarea şi stabilitatea lucrărilor miniere în cariere", Ed. Litografică a Institutului de mine, Petroşani, 1984.

10. C.V. Secu, C. Patriche, I. Vasiliniuc, Aspects Regarding Correlation of the Romanian Soil Taxonomy System (2003) with WRB (2006). Ґрунтознавство, 2008, T. 9, 34, 56.

11. F. Damian, Gh. Damian, R. Lacatusu, Gh. Macovei, Gh. lepure, I. Napradean, R. Chira, L. Kollar, L. Rata, D.C. Zaharia, Carpthian Journal of Earth and Environmental Sciences, 2008, 3, 1, 85.

12. Gh. Damian, F. Damian, D. Nasui, C. Pop, C. Pricop, Carpathian Journal of Earth and Environmental Sciences, 2010, 5, 1, 139.

13. C. Zaharia, D. Şuteu, Environmental Engineering and Management Journal, 2011, 10, 11, 1693.

14. E. Petraitis, M. Pranskevičius, L.R. Izdelis, P. Vaitiekūnas, Environmental Engineering and Management Journal, 2011, 10, 12, 1935.

15. V. Petrescu, G.O. Sumbasacu, N. Sîrbu, Environmental Engineering and Management Journal, 2011, 10, 11, 1779.

16. M.E. Fortuna, I.M. Simion, M. Gavrilescu, Environmental Engineering and Management Journal, 2011, 10, 12, 1987.

17. G.R. Mocanu, A.D. Pop, G. Arghir, Acta Technica Napocensis, Applied Mathematics and Mechanics Series, 2011, 54, I, 179. 
18. M. Cresser, K. Killham, T. Edwards, "Soil chemistry and its application", Cambridge University Press, Great Britain, 1993.

19. J. Hassink, A.P. Whitmore, J. Kubat, European Journal of Agronomy, Montrouge Cedex-France, 1997, 7, 189.

20. H.E. Belkin, S.J.Tewalt, J.C. Hower, J.D. Stucker, J.M.K. O’Keefe, C.A. Tatu, G. Buia, International Journal of Coal Geolog, 2010, 60.

21. C. Panaitescu, "Petrologia cărbunilor, cocsurilor şi produselor carbonice", Ed. Enciclopedica, Bucureşti, 1991, 324.

22. M. Rebrişoreanu, E. Traistă, A. Matei, O. Barbu, V. Codrea, The impact of the bituminous coal combustion from the thermoelectric power plant from Paroşeni on the environment of Jiu Valley. Studia Universitatis Babeş-Bolyai, Geologia, Cluj-Napoca, 2002, XLVII, 1: 117-126.

23. A. Braşovan, R.F. Câmpean, G. Arghir, V. Codrea, Metalurgia International, 2010, $X V, 7,40$.

24. A. Braşovan, V. Codrea, G. Arghir, R.F. Câmpean, I. Petean, Carpatian Journal of Earth and Environmental Sciences, 2011, 6, 1, 221.

25. F. Tateo, V. Summa, M.L. Giannossi, G. Ferraro, Applied Clay Science, 2006, 33, 181.

26. F. Tateo, V. Summa, Applied Clay Science, 2007, 36, 64.

27. M. Dumitru, S. Dumitru, V. Tănase, V. Mocanu, A. Manea, N. Vrânceanu, M. Preda, M. Eftene, C. Ciobanu, I. Calciu, I. Rînoveanu, "Monitoringul stării de calitate a solurilor din România. Institutul naţional de cercetare-dezvoltare pentru pedologie agrochimie şi protecţia mediului IPCA Bucureşti”, Ed. Sitech Craiova, 2011, 82.

28. I. Rotunjeanu, "Stabilitatea versanţilor şi taluzurilor", Ed. Infomin, Deva, 2005, 351.

29. V.J. Kurth, M.D. MacKenzie, T.H. DeLuca, Geoderma 2006, 137, 135.

30. F. Gelman, R. Binstock, L. Halicz, Fuel, 2012, 96, 608.

31. F.V.M. Pontes, M.C. Carneiro, D.S. Vaitsman, G.P. Rocha, L.I.D. Silva, A.A. Neto, M.I.C. Monteiro, Analytica Chimica Acta, 2009, 632, 284.

32. H. Egnér, H. Riehm, W.R. Domingo, „Untersuchungen über die chemische Bodenanalyse als Grundlage für die Beurteilung de Nährstoffzustandes der Böden. II. Kungl Lantbrukshögskolans Annaler 26“, 1960, 199.

33. K. Ivanov, P. Zaprjanova, M. Petkova, V. Stefanova, V. Kmetov, D. Georgieva, V. Angelova, Spectrochimica Acta, 2012, Part B 71-72, 117.

34. O. Brandula, M. Lazăr, F. Faur, Research Journal of Agricultural Sciences, 2015, 47, 4, 19.

35. M. Dumitru, D. Cărăbiş, L. Pârvan, C. Sârbu, Agriculture and Agricultural Science Procedia, 2016, 10, 3-9.

36. R. Erdogan, Z. Zaimoglu, Environmental Engineering, Advances in bioremediation of wastewater and polluted soil, 2015, chapter 10. 
